\title{
FIRST RECORD OF PARTIAL MELANISM IN THE CONEY CEPHALOPHOLIS FULVA (PERCIFORMES: EPINEPHELIDAE)
}

\author{
Thiony Simon ${ }^{1}$; Jean-Christophe Joyeux ${ }^{2}$ and Raphael Mariano Macieira ${ }^{3}$
}

Universidade Federal do Espírito Santo

Departamento de Oceanografia e Ecologia - Laboratório de Ictiologia

(Av. Fernando Ferrari, 514, 29075-910 Vitória, ES, Brasil)

1'thionysimon@ hotmail.com; ${ }^{2}$ joyeux@ npd.ufes.br; ${ }^{3}$ raphaelmacieira@ hotmail.com

Many abnormalities in the coloration of fishes have been recorded, including albinism, melanism and ambicoloration (e.g. DAHLBERG, 1970). Melanism, according to Gould and Pyle (1896), is characterized by the presence of an excessive amount of pigment in tissues and skin. In fishes, melanism may occur in varying degrees of intensity (PIGG, 1998) and can, in some cases, result from injury (DAHLBERG, 1970), genetic inheritance (HORTH, 2006), intergeneric hybridization (ELWIN, 1957) or parasite infestation (HSIAO, 1941).

The coney Cephalopholis fulva (Linnaeus, 1758) is distributed in the Western Atlantic from South Carolina, USA, to Southeastern Brazil (FIGUEIREDO; MENEZES, 1980). As its Northwestern Atlantic and Caribbean counterparts, the Brazilian coney presents three color phases. The red phase is found in deep water individuals, the uniformly brown or bicolored phase (in which the upper half of the body is dark brown and the lower half creamy white) is mostly encountered in shallow water individuals and the xanthic phase (actually a morph rather than a phase) is found independently of depth (SMITH, 1971). This author suspected that the yellow variety is actually the result of a single gene, but no further information exists on this subject. The species exhibits diel changes in the pattern of coloration and the alternation between the fully brown pattern in daytime and the bicolored pattern at night has been fully documented (NEMTZOV et al., 1993). This present study describes the first recorded occurrence (DAWSON, 1964, 1966, 1971) of partial melanism in the coney.

The specimen was captured about $10 \mathrm{~km}$ off the coast of Guarapari, Espírito Santo, Southeastern Brazil, near Rasas and Escalvada islands $\left(20^{\circ} 42^{\prime} 07,8^{\prime \prime}\right.$ S e $\left.40^{\circ} 23^{\prime} 36,8^{\prime \prime} \mathrm{W}\right)$, during hook and line samplings undertaken at quarterly intervals between July 2005 and October 2007. The substrate is formed of a mosaic of calcareous algae beds, rocky and biogenic reefs and extensive deposits of unconsolidated sediments, at depths varying from 15 to $33 \mathrm{~m}$. An additional 147 coneys were captured during sampling. None, however, presented any type of coloration abnormality. The frequency of occurrence of the anomaly was therefore estimated to be $0.68 \%$. The specimen was photographed still fresh (Fig. 1a) and maintained frozen until fixation in $10 \%$ formaldehyde and preservation in $70 \%$ ethanol. The area of the melanic part of the body was estimated from a digital photography of the right side of the fish (Fig. 1a). A 1300-square grid was digitally overlaid onto the photography to determine the proportion of squares over melanic skin. As both sides displayed the some pattern and extent of melanosis, there was no need for measuring the area on the left side, and the result obtained for the right side was extrapolated for the whole body. The specimen is deposited in the fish collection of the Universidade Federal do Espírito Santo (CIUFES 0219).

The anomalous specimen is an individual of medium size (223 mm total length; $186 \mathrm{~mm}$ standard length) and apparently healthy. The melanic portion is restricted to the posterior half of the body, beginning at a vertical under the last spine of the dorsal fin and extending to the end of the tail. This corresponds to $37.7 \%$ of the corporal surface area (fins included). The excess of melanin was limited to the epidermis over the posterior extremity of body scales and over the whole scales and naked skin on the fins. The intensity of the pigmentation of the melanic area is greater on the dorsal and caudal fins, merging into a blander tonality in the lateral region of the body. The two small black spots on the top of the caudal peduncle, usual in this species (HEEMSTRA; RANDALL, 1993), cannot be seen due to the strong pigmentation in this region. The remainder of the body displays the normal coloration of an individual in the red phase (HEEMSTRA; RANDALL, 1993). In particular, the small dark-edged pale blue spots over the whole body (observed in the fresh organism (Fig. 1a) but that turned entirely dark after fixation (Fig. 1b) and the two small black spots on the tip of the lower jaw (one on each side), characteristic of the species, are present. 


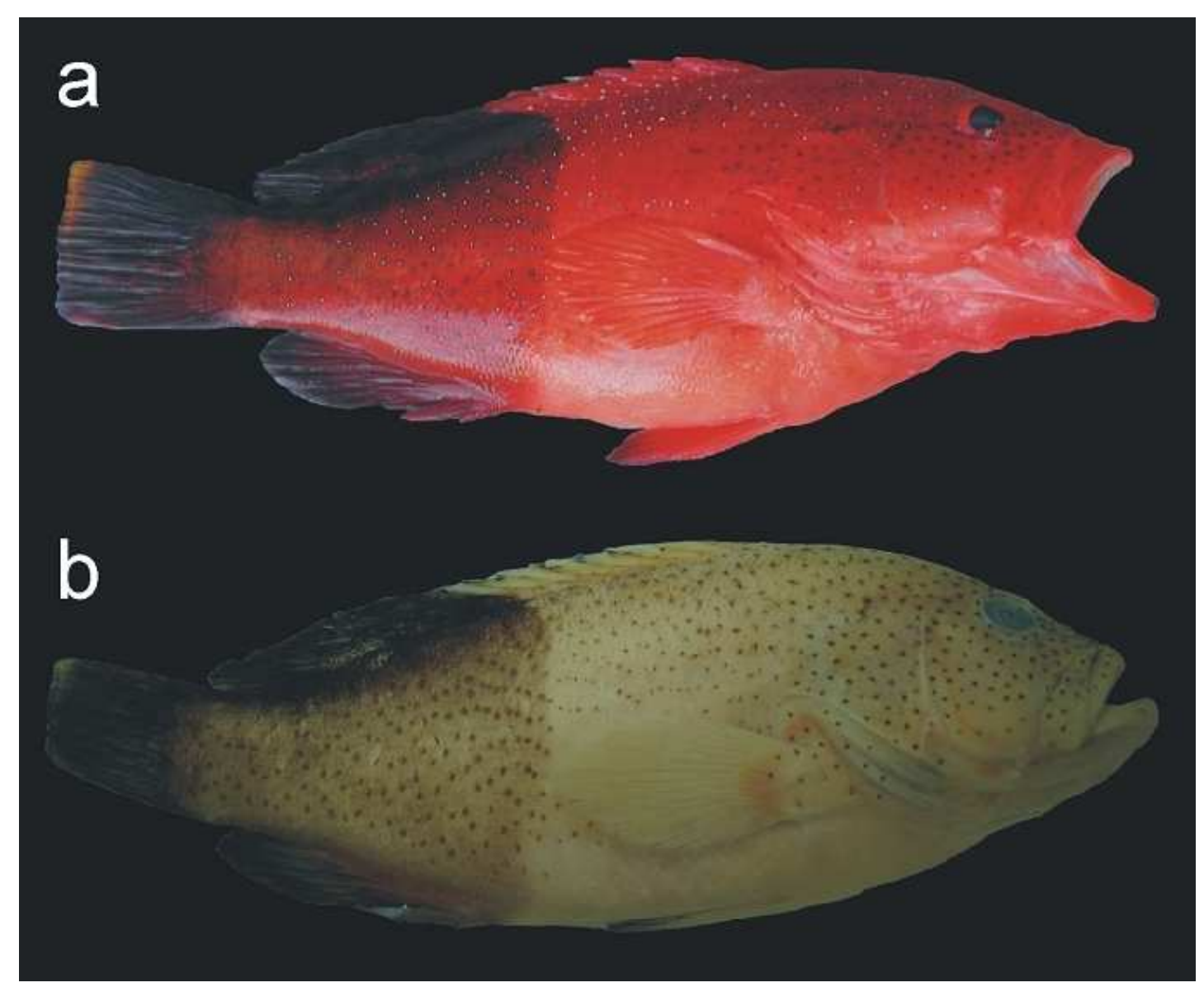

Fig. 1. Specimen of Cephalopholis fulva captured off Southeastern Brazil, showing partial melanism. (a) Freshly caught individual and (b) same individual after fixation.

It was impossible to pinpoint the cause of the melanism for the specimen reported here. However, a few hypotheses can be rejected. Melanism resulting from parasitic infestation is unlikely. For example, Hsiao (1941) reported that an Atlantic cod Gadus morhua probably developed melanism as a result of having the skin heavily infested by trematode larvae. However, no macroscopic parasite was detected in the upper tegumentary system of our specimen. Also, microscopic observation (50x) of the epidermis over the scales showed no alteration in the form or size of melanocytes (it only did so in their number) nor any difference in the appearance of unpigmented areas of melanistic and non-melanistic regions. There are cases of melanism associated with intergeneric hybridization (ELWIN, 1957) and hybrids between C. fulva and Cephalopholis furcifer are known (SMITH, 1966; BOSTROM et al., 2002). Melanism related to such an origin is, however, unlikely because all the meristic characters of the specimen (dorsal fin: IX, 15; anal fin:
III, 9; gill rakers on the first arch: 24) are typical of $C$. fulva (HEEMSTRA; RANDALL, 1993) and not intermediary between the two species as is normally observed in hybrids. In addition, no abnormalities in coloration have been reported in cases of $C$. fulva hybridization (SMITH, 1966; BOSTROM et al., 2002). The species is of wide distribution (HEEMSTRA; RANDALL, 1993) and great economic importance, representing one of the main resources extracted from reef areas on the central coast of Brazil (KLIPPEL et al., 2005). Coney have been widely studied (e.g. NEMTZOV et al., 1993; BOSTROM et al., 2002; ARAUJO; MARTINS, 2006) and the absence of any record of melanism in $C$. fulva could indicate that the occurrence of this abnormality is very rare. Probably, melanism interferes with social interactions and reproductive success, seeing that $C$. fulva is a protogynous species where males are territorial, have harems, and display a nuptial pattern of coloration (HEEMSTRA; RANDALL, 1993). 


\section{ACKNOWLEDGEMENTS}

We thank J. L. Gasparini, A. S. Martins and F. N. Coelho for providing valuable information and clues, and L. B. C. Xavier, L. F. Nascimento, V. C. Brilhante, R. G. Dalmaschio, R. L. S. Gualandi and M. S. C. Hora for helping in field work. Sampling was funded by Instituto Estadual de Meio Ambiente e Recursos Hídricos do Espírito Santo (IEMA), with T. Simon being partly supported by a fellowship from the same institution.

\section{REFERENCES}

ARAUJO, J. N.; MARTINS, A. S. Age and growth of coney (Cephalopholis fulva), from the central coast of Brazil. J. Mar. Biol. Ass. U.K., v. 86, p. 187-191, 2006.

BOSTROM, M. A.; COLLETTE, B. B.; LUCKHURST, B. E.; REECE, K. S.; GRAVES, J. E. Hybridization between two serranids, the coney (Cephalopholis fulva) and the creole-fish (Paranthias furcifer), at Bermuda. Fish. Bull., v. 100, n. 4, p. 651-661, 2002.

DAHLBERG, M. D. Frequencies of abnormalities in Georgia estuarine fishes. Trans. Amer. Fish. Soc., v. 99, n. 1, p. 95-97, 1970.

DAWSON, C. E. A bibliography of anomalies of fishes. Gulf Res. Rep., v. 1, p. 308-399, 1964.

DAWSON, C. E. A bibliography of anomalies of fishes. Gulf Res. Rep., v. 2, Supplement 1, p. 169-176, 1966.

DAWSON, C. E. A bibliography of anomalies of fishes. Gulf Res. Rep., v. 3, Supplement 2, p. 215-239, 1971.

ELWIN, M. G. Pathological melanosis in an intergeneric hybrid. Nature, v. 179, n. 4572, p. 1254-1255, 1957.

FIGUEIREDO, J. L.; MENEZES, N. A. Manual de peixes marinhos do sudeste do Brasil. V. III (Teleostei 2). São Paulo: Museu de Zoologia da Universidade de São Paulo, 1980. 90 p.

GOULD, G. M.; PYLE, W. L. Anomalies and curiosities of medicine. Philadelphia: W. B. Saunders, 1896. 968 p.
HEEMSTRA, P. C.; RANDALL, J. E. Groupers of the world. FAO Fisheries Synopsis. Rome: Food and Agriculture Organization, v. 16, n. 125, 1993. 382 p.

HORTH, L. A sex-linked allele, autosomal modifiers and temperature-dependence appear to regulate melanism in male mosquitofish (Gambusia holbrooki). J. expl Biol., v. 209, n. 24, p. 4938-4945, 2006.

HSIAO, S. C. T. Melanosis in the common cod, Gadus callarias $\mathrm{L}$., associated with trematode infection. Biol. Bull., v. 80, p. 37-44, 1941

KLIPPEL, S.; MARTINS, A. S.; OLAVO, G.; COSTA, P. A. S.; PERES, M. B. Estimativas de desembarque da pesca de linha na costa central do Brasil (estados do Espírito Santo e Bahia) para um ano padrão (1997-2000). In: COSTA, P. A. S.; MARTINS, A. S.; OLAVO, G. (Ed.). Pesca e potenciais de exploração de recursos vivos na região central da Zona Econômica Exclusiva brasileira, p. 71-82. Rio de Janeiro: Museu Nacional, 2005. $248 \mathrm{p}$.

NEMTZOV, S. C.; KAJIURA, S. M.; LOMPART, C. A. Diel color phase changes in the coney, Epinephelus fulvus (Teleostei, Serranidae). Copeia, v. 1993, n. 3, p. 883$885,1993$.

PIGG, J. Melanism in Longnose Gar, Lepisosteus osseus Linnaeus (Lepisosteidae). Proc. Okla. Acad. Sci., v. 78, p. 123-123, 1998.

SMITH, C. L. Menephorus Poey, a serranid genus based on two hybrids of Cephalopholis fulva and Paranthias furcifer, with comments on the systematic placement of Paranthias. Am. Mus. Novit., n. 2276, p. 1-11, 1966.

SMITH, C. L. A revision of the American groupers: Epinephelus and allied genera. Bull. Am. Mus. nat. Hist., v. 146, p. 67-242, 1971.

(Manuscript received 30 April 2008; revised o8 January 2009; accepted 20 January 2009) 